O autor apresenta um estudo de caso da sua prática pedagógica com estudantes do segundo ano de graduação fazendo estágio em turmas que vão do jardim de infância à oitava série do Ensino Fundamental. No programa dessa disciplina o professor introduz a cultura visual. Como os estudantes vêm com idéias preconcebidas sobre arte, arraigadas ao modernismo, seus objetivos são: ajudá-los a compreender que imagens são constituídas de idéias, valores e crenças; que isto é tão verdadeiro para a arte popular quanto para a arte erudita; que as idéias, valores e crenças que constituem as imagens devem ser objeto de crítica e não apenas de celebração. No decorrer do estudo de caso, exercícios são descritos com alguns exemplos que revelam complexas negociações de aceitação, resistência e apropriação.

Palavras-chave: cultura visual, pedagogia, estudo de caso em negociação. 


\section{A visual culture pedagogy: \\ A case study in negotiation}

\section{Paul \\ DUNCUM}

The author offers a case study of his own pedagogic practice with second year undergraduate university students enrolled in a kindergarten to grade 12 ( $\mathrm{K}$ 12) pre-service art teacher training program in which he introduces visual culture. Since his students come with preconceived ideas about art that are grounded in modernism, his goals are: to have students understand that images are constitutive of ideas, values and beliefs; that this is as true of popular art as it is of fine art; and that the ideas, values and beliefs of which all images are constituted should be subject to critique and not simply celebrated. A number of exercises are described with some examples. Throughout, students' complex negotiations of acceptance, resistance and embrace are noted.

Keywords: visual culture, pedagogy, case study in negotiation. 


\section{First Things First}

I begin on the first day, even before I hand out the syllabus, by asking my students to write down three to five topics they would like to be able to teach in their first semester as teachers. They are to imagine that they are in an ideal school, with all the physical resources they require and all the support they could ask for from their fellow teachers, administrators and parents. The students jot down their lists, and without any comment from me I collect them for future reference. A few weeks later when they have presumably forgotten all about that first exercises, I ask them to write down a list of the things in their life that are the most important to them: what interests them most? What do they fear? They are to consider who they are, what defines them, and to think of what is consequential to them as late teens/early 20s, male or female, Americans, students, citizens of the early 21 st century; otherwise, I make no suggestions of how they might answer. Again, without comment from me, I collect their responses. The following week I remind the students of the two lists they had previously compiled, and I put on the blackboard a summary of both. The following is the first list from last semester of 16 students:

Painting (10),

Drawing (10),

Elements (other than color) (10)

Principles/Design (9)

Color (4),

Personal expression (4)

Unspecified techniques/skills (5)

3D or Sculpture (4),

Textiles (3),

Fashion Design (3),

Ceramics (3),

Community murals (2),

Technology (2),

Portraiture (2)

Still life (2),

Watercolor (1),

Clay sculptures (1) 
While the study of visual culture has been advocated by many art educators now for some years (e.g., DUNCUM, 2001; FREEDMAN, 2003; TAVIN, 2003), there remains little idea of what is being undertaken in classrooms. Some reports have been made on classroom practice (e.g., DUNCUM, 2006; TAVIN \& ANDERSON, 2003; VIDIELLA \& HERNANDEZ, 2006; WALKER, et. al., 2006), but most reports are not especially detailed. Many reports highlight only success and fail to acknowledge difficulties. I write this paper in consideration of Williamson's (1981/82) justification for writing in detail of her media studies class. Teaching, she wrote, "is like sex - you know other people do it, but you never know exactly what they do or how they do it" (p. 83).

In this paper I describe my pedagogy in an undergraduate foundations course for pre-service kindergarten to grade 12 (K-12) art teachers. My students are mostly 19 and 20 years of age and mostly female. With few exceptions, during their school years they had a formalist and media orientated art education, plus some art history. To date this approach is largely reinforced rather than challenged during their first introductory year - mostly, they practice drawing and design - before they enter the art education, teacher-training program. I happily report that changes are on the way for this introductory year, but until now their first year has largely consisted of exploring a variety of traditional media and art history. The students are bright and highly motivated, but they come carrying the baggage of modernism, and especially formalism. Thus my primary task is to turn them around, to inculcate alternative ideas grounded partly in postmodernism: The prime significance of images lies in their being constitutive of ideas, values and beliefs; that this is a true of popular art as it is of fine art; and that the ideas, values and beliefs of which all images are constituted should be subject to critique and not simply celebrated. These are my starting points. Schoolteachers whose students do not necessarily carry the burdens of preconceived, modernist ideas about imagery would start elsewhere, however, adopting the view that teachers should start from where their students are, I endeavor to re-orientate mine by considering some fundamentals of contemporary sociocultural life. 
Pencil (1),

Art history (1),

Expressionism (1),

Surrealism (1),

Art Theory (1).

The following is the second list.

My religious beliefs (5)

My boyfriend (5),

Terrorism (4),

Health (4)

Racial intolerance (3)

Global warming (3)

Specific family members (3)

A love of art (2)

Environmental degradation (2),

How the media lies (2)

How the media represents gays and women (2)

The vulnerability of children (2)

Sexually transmitted diseases (2)

Women's rights (2)

Peer pressure (2)

Parental pressure to succeed (2)

Iraq (2),

The Bush administration (2),

Religious intolerance (1)

America's place in the world (1)

Animal rights (1)

Basketball (1)

Fear of failing university studies (1)

AIDS (1)

Fear of death (1).

These specific lists are typical of each class I have taught over the past few years. As the second list goes up on the board I usually see several students with grins on their faces, and I ask them for their thoughts. The ensuing discussion ensures that 
the huge disparity between the two lists emerges. Elements, principles, and genres and movements of art are seen by some students as comparatively banal, and I express mock surprise that none sees the elements or the principles, or specific art genres, or specific media, or specific art history movements as central to who they are. If such disparity exists among them, they who are demonstratively invested in visual art, how much less interesting is the traditional art curriculum for most of the school students they will teach? How much less defining? Some students appear to get the point; they seem to reconsider their previous priorities, though among others resistance is palpable. Based on statements they make at other times I can see them thinking that this is an art class, not social studies, and many seemed confused. This is not what they signed up for.

\section{Readings and DVDs}

I have them read a number of articles on how teachers are already practicing visual culture in their own K-12 classes. We read articles such as Gude's (2004) on postmodern elements and principles, Tavin and Anderson's (2003) on teaching Disney in a grade 5 class, and lately I have them read several chapters from my own anthology of classroom practices (DUNCUM, 2006), including those on TV reality shows, advertising, political campaigns, and media violence, all of which involve crossovers from fine and popular art. I try to ensure an atmosphere of free and open discussion where I clearly articulate my views as my own but respect theirs. It is a delicate balancing act.

Responses to these articles vary a great deal and in utterly unpredictable ways. One week a student who takes umbrage at one article will be placated the following week by another that virtually says the same thing, while another student who is happy with the first article will strongly oppose the second. As novices they often have no perspective on what is important and what is peripheral. After reading an article on contemporary popular culture some students object that visual culture is ahistorical and opposed to fine art. During a discussion that 
lead from Leonardo's Mona Lisa to the film Mona Lisas Smile, staring Julia Roberts, one student indignantly declared, "Well I'm not teaching about Julia Roberts!" Overall, I have come to see this as the uneven negotiation between their own preconceptions, wanting to understand what is new and challenging to them, wanting to please me, yet unprepared to abandon cherished positions. Students complain that too many of the assignments reported in the articles deal with collage, or with computers, or with ideas at the exclusion of developing skills in traditional media. They complain that the readings put a priority on discussion in the classroom whereas they feel art classes should be primarily about making art. While they often admire teachers for tackling controversial issues, they cannot envisage themselves doing so. I talk to them about needing to know their students well and to garner the support of parents and school the administration, and I offer Polanieki's (2006) example of how to work with cutting-edge material in a deeply conservative environment. Students nod in agreement, realizing, I imagine, that deciding on whether to deal with controversial material will be well into the future and well beyond my control.

To supplement these readings we watch a number of DVDs, mostly from the Education Media Foundation based in New York. Mickey Mouse Monopoly (SUN, 2001) deals with Disney stereotypes of races, genders and commercialism, and the PBS Frontline Program The Merchants of Cool (SULLIVAN, 2001) deals with product placement, media control, and media self-reference. Resistance to these programs also comes in several forms. Since some of the programs switch between short snippets of advertising or Disney animation, with the high production values with which students are familiar, to the brutal honesty of video showing middle-aged academics critiquing behind their desks, students find it easy to attack the messengers. The medium appears to be the message, where beauty overbears thought. Although these students attend a top research university, often their response, typical of undergraduates everywhere, is, "What would academics know?" It does not help that some of the academics appear to be angry; 
in a culture that values public politeness, strongly expressed indignation is jarring. When required to critique Disney, some of my students respond as do those reported by Sun (2004): How dare anyone attack Disney! Like Sun's students, a minority of my students even appear to accept the traditional, gendered roles assigned by Disney productions; just as in many Disney media female characters are dependent upon male characters, a few of my female students appear to accept that as females they are naturally dependent upon males. Like Williamson (1981/82) students who failed to see particular biases in the media because those biases looked to them like the truth, some of my students refuse to see Disney's constructions as anything but natural.

Nevertheless, some students do seem shocked by the blatant and negative stereotypes to be found in many media productions, though many students are unprepared to assign responsibility to the makers, and many continue in refusing to see that it could be the art teacher's responsibility to counter such stereotypes. This is a matter for the social studies teacher they say; that images are constitutive of stereotypes and carriers of ideology continues to be lost. Disconcertedly, examination of Disney and other popular media often appears to reinforce the modernist divide between fine art as morally worthy and popular art as degenerate, and they, assuming modernist ideas, see themselves saving their future charges from the pernicious influence of popular art by means of the higher values of the fine arts.

\section{The Big Hypertext Assignment}

In contrast to this resistance, a curious thing happens when it comes to the big, end of semester assignment. Students are required to choose an image - I stress any image - and develop a hypertext PowerPoint from it. I stress that the image they chose can be of any kind so long as they have some idea of what they want to do with it and I can see it has potential. Almost all images turn out to be sufficiently rich. The curious 
thing is that most students do not choose a fine art image; most choose an image from their own popular culture. A few students will even say, "You mean I can work on ...." mentioning their idiosyncratic enthusiasm for a favorite television program, or movie, or a multi media phenomenon like Harry Potter. They seem scarcely able to believe that they can indulge their passion as fans. Such students are not necessarily prepared to admit that they favorite cultural form should be critiqued for unfortunate ideas, but at least the barrier against considering popular culture is broken down at this point.

Leading up to this assignment I introduce what I call the flora model of modernism verses postmodernism, which I have appropriated from Brent Wilson (2000). A modernist/formalist approach to imagery I argue is like a tree, with the branches being all the issues images deal with, the roots being all the mini narratives of art history, and the trunk being what the issues and histories have in common, namely the elements and principles, and media. By contrast, a postmodernist approach to imagery is like the rhizomic structure of grass. Like grass, a postmodern approach stresses many, often-unpredictable interconnections, related by associations. Where modernism is essentialist and hierarchical, postmodernism is pluralist and socially leveled (EFLAND, 1992). Furthermore, I suggest that a treelike structure is highly vulnerable: like a tree that can be cut down killing both branches and roots, if we take away the elements and principles it might appear that we destroy art itself. On the other hand, a rhizomic structure is highly adaptable and very difficult to destroy; as soon as one part is destroyed another part will grow. Finally, I suggest that a rhizomic structure is akin to the way humans think, especially imaginative people like artists and would-be art teachers.

Students select an image (or picture of a three dimensional artifact) of any kind. It must, be an image of richness such that it can be related to three or four issues by means of other pictures and written texts, music or sounds. The written texts can be of any type; for example, quotes from books, articles, poems, song lyrics, and student's own reflections. As suggestions for issues I offer the following: 
Sexism

Racism

Nationalism

Patriotism

Globalization

Xenophobia

Homophobia

Localism/Community

Censorship

Violence

Consumerism

Citizenship

Other

The other images to which the first is connected must include at least three of the following kinds:

Popular art

Traditional Western fine art

Traditional Non-Western fine art

Indigenous art

Contemporary fine art

Folk or vernacular art

Community art

The student's own visual images

I suggest that the kind of connections will vary. Sometimes they will be informative, or critical, or satirical, or ironic, and so on. Criteria for assessment include: the validity, clarity, and complexity of the connections; subtlety, irony, invention and surprise; depth of exploration though images and texts; communicative composition of images and texts; technical facility, including ease of access and movement through the hypertext; the quality of images; and writing skills.

Some students choose an image clearly illustrative of one or more issues. Others will choose an image they like with only the most vague of ideas as to its significance, and I need to talk them through issues to which it does, or can be made to, relate. Occasionally a student will have no idea why they have 
chosen their image. So long as I can see for myself that it has potential I leave it to the student to discover this for him or herself, believing images that speak at a deeper than conscious level may have more potential than ones chosen for conscious reasons. For example, this certainly appeared to be the case when a young, male student chose an advertisement for a product - he did not even know what the product was - which used a photograph of an adolescent male reclining in a chair with a older, somewhat predatory women towering over him.

The images the students choose are exceptionally varied. They have included icons of fine art such as the Mona Lisa and Geurnica, high art fashion photography, and a contemporary fine art graphiti artist; other students have chosen movies as diverse as the recent Crash to the classic Gone with the Wind, advertisements for products as diverse as clothing stores to ice cream, comics as different as Snoopy and Wonder Woman, and magazine covers as diverse as Rolling Stone and a early 20th century French magazine for fashion. Other examples have included photographs of various media celebrities such as the Olsen Twins and Marylyn Monroe, music idols like Kanye West and Bob Marley, a religious roadside billboard, John Lennon's memorial in New York, an AIDS poster, and an advertisement for breakfast cereal that uses comic figures but references Leonardo's The Last Supper. As for the issues student have chosen, in addition to the ones I suggest, listed above, students have used: competition, safety, transportation, private schools, heroism, cultural appropriation, drugs, war, family values, and, surprisingly, consanguineal relationships.

To facilitate inquiry, the class spend two hours for five weeks in a computer lab exploring the intricacies of PowerPoint and gathering material mostly from the net. Nearing the time for assessment the students spend untold hours by themselves. Although there is better software for this assignment, their expense prohibits them ever being available in schools. Toward the end of the assignment, we gather to offer a class critique to assist students to think broader, to offer further examples, and to solve problems. Suggestions are sometimes technical - websites to find particular material, how to insert a movie, or how 
to make a point visually clearer, for instance- but also to ask for further explanation or examples, or to strengthen links between ideas and images. Often students find they are working on similar issues and can readily offer advice. Sometimes there is honest disagreement. It becomes apparent that one student's hypertext can link to another's, and yet another's, and if time permitted it would be possible to link almost everyone's hypertext to form a huge hypertext. The notion of intertextuality seems well grasped, including links between popular and fine art, and contemporary and historical imagery and ideas. It is generally at this point that the class is humming; everything appears to be coming together, everyone appears engaged.

Following the critique students are charged with responding over the next week or two before handing in the assignment, and my assessment is partly informed by how students have responded to the class critique: Have they taken up suggestions? Do they seem to understand the point of the suggestions?

\section{Some Examples}

I include now a few illustrative examples. Priscilla chose the trailer to the movie The Passion of Christ and dealt with religion, pain and suffering, and religious icons. She examined differences in Christian, Jewish and Islamic imagery as constitutive of their particular characteristics as well as images of religious controversies (of which there is no shortage in the United States). The allegations of anti-Semitism, which the film drew in the media, led Priscilla to consider the holocaust and racism in the United States. Under religious icons she examined many historical and contemporary images of Christ, including the idea of Jesus as father, as shepard, and as judge, as well as images of Christ as both a white person and an African American. Paintings by, for example, Rouault and Dali led to popular images and commercialism, which included a last supper on a lunch box, Jesus on an ash tray, a "Cool Jesus" on a T shirt, and Jesus as an action figure. Priscilla concluded with a statement about her own religious faith. 
Typically, some students like Priscilla choose contemporary images and work backwards historically while others start with a historical image and work forwards. Laura linked the Venus De Willendorf to notions of both male and female beauty over the centuries. Of women she included, for example, figures from Mycenae, Cranach the Elder's painting The Judgment of Paris, 19th century pornography, paintings by Modigliani, contemporary beauty pageants, plastic surgery, and eating disorders. Of men she included many images from Greek Kouros to paintings by Lucian Freud as well advertising for men's toiletries.

Krysten chose a still image from the Disney broadway show Avenue $Q$ and used four of its central themes as her issues: racism, homosexuality, sexism, and censorship. Each is introduced with song lyrics from the show. With racism she used photographs of hangings by the Klu Klux Klan and anti-semetism in Europe with woodcuts from the middle ages. With homosexuality, she examined TV stereotypes of gays and contemporary cartoons that deal with it as controversial, as well as different historical views of it as demonstrated in images from the ancient cultures of China, Greece, and India. Krysten dealt with sexism by showing very different body types, historical and contemporary, and she illustrated the struggle for women's rights with photographs of demonstrations and key figures in the suffragette movement. She considered censorship with examples of banned books, music, films, and how it has operated during times of war.

Tanya chose a poster of the film Amelie in which the central character looks up at the viewer in a conventional feminine way, allowing Tanya to consider the overlapping issues of femininity, the roles of women in society, and women's visual representation. She described why she liked being feminine and illustrated her own negotiation with it in terms of peer pressure and advertising with pictures of female accessories like handbags, shoes and jewelry. Elsewhere she examined how women's visual representation, past and present, constitute certain stereotypes, including mother, housewife, delicate flower, femme fatale, and virgin, though she also included pictu- 
res of women she called, "with personality." Tanya considered these stereotypes often to be masks that women wear deliberately to protect their real selves. She also examined ideals of face and body, comparing different body shapes - pear, straight and apple - as well as different ethnic facial features. She examined how over past millennia the golden section has been used to construct ideal faces, bodies, paintings, and architecture. Tanya also considered the use of pictures as a source of remembrance as employed in the film Amelia, and she linked this to the functions of family heirlooms like quilts and hand-me-down wedding dresses.

Some students, like Tanya, choose to relate their hypertext to themselves. This was especially true of Sara who chose a black and white, documentary style photograph of herself, which she related to several aspects of herself - her Polish-Russian-Lithuanian American identity, her class, her parent's divorce, her religious faith, and her love of the arts. In dealing with her ethnicity, for example, she writes of the American notion of cultural assimilation as a melting pot, and ideas of freedom, liberty, and the American Dream. The characteristics she describes are related so, for example, her ethnic identity is related to her particular love of Polish, Russian and Lithuanian art. She illustrated this love with many examples of art from these three countries, describing their particular qualities and unique histories. Each aspect of herself is then related to aspects of several of her friends; one friend is also of Russian decent, another's parents is also divorced, and so on. With each friend their own characteristics are described, both where they overlap with Sara's and where they were dissimilar, so that taken as a whole Sara described a complex network of relationships spiraling out from herself and covering many issues: how different people choose to her deal with peer pressure, their education, their religious beliefs, their ethnic status, and so on. Into this mix were also woven Sara's own majority position as white and Christian compared to a friend who is of color and Hindu - partly illustrated with images of Christian and Hindu art - and which, in turn, led to material on white privilege and racism, illustrated with images of stereotypical African Americans in popular culture 
and orientalist paintings by the likes of Delacroix. Statistics on divorce rates was linked to statistics on working mothers and images of TV families over the past few decades. In each case, Sara included definitions for terms and a voice over - her own, or parents or friends - each telling his or her own story.

\section{Partial Successes}

As many teachers have found when teaching about popular media with students, developing a critical understanding frequently falls short of the teacher's hopes or expectations (e.g., BUCKINGHAM \& SEFTON-GREEN, 1994; CUMMINGS, 2007; WILLIAMSON, 1981/22; POLANIECKI, 2006). Among my students those who tend to be the most resistant to considering visual culture in ideological terms are the pre-existing fans of a particular site. The student who explored Harry Potter, for example, refused to stray much beyond the phenomenon itself. She was unprepared to consider it in terms of commercialism, ancient tales, other children's books, or any of the other many suggestions I and other students made. What a fan's celebration demonstrates in motivation does not necessarily translate to a broader interest and certainly not to considerations of ideology. A fan can see that their beloved cultural form deals with racism or sexism, but they are usually deeply resistant to seeing their cultural form itself as racist or sexist, presumably because they feel this would reflect badly upon them. Williamson $(1981 / 82)$ argues that such students need to be shocked into a crisis, though I have been reluctant to do this. Pushing students too quickly can be counter productive, and I consul myself that all learning takes time and all I am attempting to do is initiate a process. Dealing with a particular popular culture site in art education is not enough, but it is a starting point.

Others students appear to fulfill the assignment without allowing it to touch them deeply. They may even be passionate about racism, but as white students in a predominantly white environment racism is an easy target of indignation. Environmental issues, media censorship, and many others are often 
equally suspect in this regard. As issues outside personal experience, students' investigation of these issues remains impersonal, touching the mind but not the heart.

On the other hand, there are clear exceptions, as the assignments from Tanya and Sara demonstrate. Also, exploring issues in an intellectual way should not be dismissed for it is impossible to say at what personal level students are dealing with these issues; offering up issues in class in a purely intellectual fashion not only fits the general expectation of scholarship but may act as a form of protection. It cannot be an accident that certain topics, though not suggested by me, regularly appear from my mostly young, female students; notably, ideals of beauty, body and facial types, and eating disorders. A student who dealt with family dysfunction on a popular television program might well have been drawn to it because of her own family background. An ostensibly religious student who began with Michelangelo's Pieta finished with graffiti she found in the women's bathroom, which claimed that if Jesus thought he was the Son of God perhaps he was insane. I do not know, but I suspect this inclusion was a, perhaps unconscious, negotiation with religious doubt. Ethnic minority students deal with racism in ways that touch them at levels I cannot imagine.

To what extent students are merely giving me back what they think I want, seeking to please me, or are truly engaged in discovering new ways to consider popular visual images, is impossible to tell. In any course student motivations vary, change during a course, and are always layered (WILLIAMSON, 1981/ 82; BUCKINGHAM \& SEFTON-GREEN, 1994). Although by the end of the class my students invariably appear proud of their hypertext assignment, it is hard to say to what extent its general lessons are integrated into their thinking. The student who added to an assignment dealing with contemporary, controversial issues a completely unrelated section on elements and principles gave me pause.

\section{Finally, For Now}


My class does not ground students in all of the basic understandings of visual culture I consider important. We do not consider culture in economic terms, and we deal with the sociocultural dynamics of designer capitalism with only a gossamer touch. For some students discussions on postmodernism appear to go over like low flying aircraft. For students whose national culture is American popular culture, it is also difficult to deal with cultural globalization in any meaningful way. I take the view that turning their views around is a developmental process and all I can do is lay the groundwork. We do not deal with the foundational theoreticians of visual culture like Hall, Mitchell, Foucault, or Barthes, let alone Lacan. We do not even look at the many textbooks that introduce visual culture. We barely consider art educators who are advocating visual culture. For students who are mostly concerned with how to survive in the classroom it seems best to go past theory straight to how others are developing visual culture curriculum. However, we do not even have the time to build upon the hypertext assignment to develop age-appropriate K-12 curriculum. Thus, how this work gets translated into future classrooms, if at all, is at this stage an open question. I can only hope I have sown seeds.

Finally, this work opens up a number of research questions. For example, in teaching from a visual culture perspective, what is to count as success? How can success be assessed? What accounts for success and what accounts for failure, or partial success? What percentage of students do we consider when we talk of success? And what pedagogic practices appear to have the most potential?

\section{References}

BUCKINGHAM, D., \& SEFTON-GREEN, J. (1994). Cultural studies goes to school: Reading and teaching popular media. London: Taylor \& Francis.

CUMMINGS, K. L. (2007). Webs, windows, and reflections: Experiences in 
a secondary art classroom. Unpublished doctoral dissertation, University of Illinois at Urbana-Champaign.

DUNCUM, P. (Ed). (2006). Visual culture in the art class: Case studies. Reston, VA: National Art Education Association.

EFLAND, A. (1992). Art education and postmodernism: Curriculum programs at century's end. In L. Pironen (Ed.), Power of images: INSEA 1992 (p. 114-121). Helsinki: INSEA Findland.

FREEDMAN, K. (2003). Teaching visual culture: Curriculum, aesthetics, and the social life of art. New York: Teachers College Press.

SULLIVAN, M. (Executive Producer), \& Goodman, B. (Director). (2001). The merchants of cool. [Television broadcast]. New York: Public Broadcasting Service.

GUDE, O. (2004). Postmodern principles: In search of a 21 st century art education. Art Education, 57(1), 6-14.

POLANIECKI, S. (2006). Teaching through TV: Transformative encounters with constructed reality. In P. Duncum (Ed.), Visual culture in the art class: Case studies (pp. 47-55). Reston, VA: National Art Education Association.

SUN, C. (Producer), \& Picker, M. (Director). (2001). Mickey Mouse monopoly: Disney, childhood and corporate power. New York: Media Education Foundation.

SUN, C. (2004). Staying true to Disney: College students' resistance to criticism of The Little Mermaid. The Communication Review, 7(1), 35-55.

TAVIN, K., \& ANDERSON, D. (2003). Teaching (popular) visual culture: Deconstructing Disney in the elementary classroom. Art Education, 56(3), 21-24, 33-35

TAVIN, K. (2003). Wrestling with angels, searching for ghosts: Towards a critical pedagogy of visual culture. Studies in Art Education, 44(3), 197213.

VIDIELLA, J., \& HERNANDEZ, F. (2006). Beyond Lucian Freud: Exploring body representations in children's culture. International Journal of Education Through Art, 2(2), 105-117.

WALKER, S., DAIELLO, V. HATHEAY, K., \& RHOADES, M. (2006). Complicating visual culture. Studies in Art Education, 47(4), 308-325.

WILLIAMSON, J. (1981/2). How does girl number twenty understand ideology? Screen Education,40, 80-87.

WILSON, B. (2000). Of Diagrams and Rhizomes: Disrupting the content of art education. 2000 International Visual Arts Conference: Art Education and Visual Culture (p. 25-40). Taipei, Taiwan: Taipei Municipal teachers College. 


\section{Acknowledgments}

I wish to acknowledge all of the undergraduate students I have taught that have contributed to this paper, especially those named: Kyrsten Blinstrup, Tanyanan Boonrougeng, Sara Mackus, Priscilla Reisinger, and Laura Wittneben.

\section{PAUL DUNCUM}

é professor de Arte-Educação na School of Art and Design da University of Illinois, Urbana Champaign. Tem publicado extensivamente sobre cultura visual, estética do cotidiano e desenho infantil não solicitado. É co-editor do livro On Knowing: Art and Visual Culture, publicado pela Canterbury University Press. 